\title{
Relation between Career Decidedness and Subjective Wellbeing in University Students: Does Hope Mediate the Link?
}

\author{
Ümüt Arslan* \\ Guidance and Psychological Counseling Department, İzmir Democracy University, İzmir, \\ Turkey \\ ORCID: 0000-0002-3611-9607
}

\begin{tabular}{|c|c|}
\hline Article history & eer decidedne \\
\hline $\begin{array}{l}\text { Received: } \\
15.03 .2021\end{array}$ & $\begin{array}{l}\text { wellbeing, and hope can be a positive and significant factor for future } \\
\text { success. This study aims to examine the model which hypothesized the }\end{array}$ \\
\hline $\begin{array}{l}\text { Received in revised form: } \\
09.09 .2021\end{array}$ & $\begin{array}{l}\text { mediating role of hope in the link between career decidedness and } \\
\text { subjective wellbeing of Turkish university students. Data were collected } \\
\text { from } 376 \text { students ( } 269 \text { women and } 107 \text { men) from universities in Izmir, }\end{array}$ \\
\hline $\begin{array}{l}\text { Accepted: } \\
04.10 .2021\end{array}$ & $\begin{array}{l}\text { Turkey. The Career Decidedness Scale, the Dispositional Hope Scale, } \\
\text { the Positive and Negative Affect Schedule, the Satisfaction with Life }\end{array}$ \\
\hline Key words: & Scale and a demographic information form used as measurement tools. \\
\hline Key words & $\begin{array}{l}\text { Pearson Correlation Test and regression-based path analysis (PROCESS) } \\
\text { were used to analyse the data. Only four percent of the participants } \\
\text { received career counseling. Pearson correlation test shows a positive } \\
\text { correlation between all scales }(\mathrm{p}<.001) \text { except negative effect and this } \\
\text { one expectedly shows negative correlations with all scales }(\mathrm{p}<.01) \text {. The } \\
\text { model testing via PROCESS Macro Model } 4 \text { indicated that career } \\
\text { decidedness and hope showed a direct effect on subjective wellbeing (p } \\
<.001) \text { and supported the mediating role of hope between career } \\
\text { decidedness and subjective wellbeing ( } 95 \% \text { LLCI }=.86 \text { and ULCI = } \\
1.40) \text {. The role of hope in career development to increase subjective } \\
\text { wellbeing with implications of the results and suggestions are discussed } \\
\text { for counselors and researchers. }\end{array}$ \\
\hline
\end{tabular}

\section{Introduction}

After starting university, students' social and economic circumstances may change dramatically (Andersen \& Vandehey, 2011; Yeşilyaprak, 2019). The challenges students face in university are frequently different than what was expected (Serlachius et al., 2007). Many changes, such as living alone, taking responsibility, and making decisions independently, are experienced for the first time after starting university (Andersen \& Vandehey, 2011). These challenges can present opportunities for students to grow and develop valuable life skills. Indeed, university years are significant for career development (Savickas, 2005) and one of university students' main tasks is to make career decisions (Evans et al., 2009; Super, 1980). University students inquire about career opportunities, make decisions to improve

\footnotetext{
* Correspondency: umut.arslan@idu.edu.tr
} 
opportunities, and implement plans (Judge \& Bretz, 1992). These decisions are more likely based on emotions than cognition (Bjork et al., 2004). New developments, globalization, and increased opportunities make it difficult to decide about a career (Gati \& Asher, 2001; Li et al., 2019). The views on career choices may cause students to make new and risky decisions that can lead to long-term results (Herrnstein \& Prelec, 1991). For example, students who drop out of school suffer from outcomes with their schools, families, and economic environment, called withdrawal costs in the education economy (Şimşek, 2013). Even though university students cannot fully grasp the results of their decisions, they all have a cost (Reyna \& Farley, 2006). Between 2014 and 2018, the number of students that withdrew from university increased from 135,137 to 408,948 in Turkey (Oktay, 2019).

Career decidedness helps students solve career-related problems and take steps to reach careerrelated goals. Likewise, career-related issues should be addressed to help university students increase subjective wellbeing. In the process of achieving career certainty and subjective wellbeing, hope may be a significant factor, as it encourages individuals to believe in themselves, gives motivation, and encourages them to achieve their future aims (Rand \& Cheavens, 2009). Studies show career decidedness has a positive relationship with hope (Hirschi, 2014) and subjective wellbeing (Arnold, 1989; Lounsbury et al., 1999; Lounsbury et al., 2005; Uthayakumar et al., 2010). At the same time, the relationship between hope and subjective wellbeing has been studied and found to be positively correlated (Bailey \& Synder, 2007; Muyan-Yılık \& Demir, 2019; Peterson \& Seligman, 2004; Synder, 2002; Yalçın \& Malkoç, 2015).

\section{Career Decidedness}

University years are frequently the most important period for career development (Super, 1980). Career decidedness is the individual's commitment and belief (Restubog et al., 2010) and a developmental stage of thoughts and decisions about the career (Osipow, 1999), stands out as a core point in this timeline (Lounsbury et al., 1999). Career decidedness positively influences academic success in university life and helps to solidify goals to be reached (Uthayakumar et al., 2010). On the other hand, difficulties with career decidedness and questioning career preferences are expected to impact students' cognitive and emotional development during university years (Hinkelman \& Luzzo, 2007; Super, 1980). Addressing career issues and improving career decidedness can increase students' life quality in university (Fitzpatrick \& Costantini, 2012). Therefore, career decidedness has been studied with several variables such as anxiety (Campagna \& Curtis, 2007), career orientation and adaptability (Li et al., 2019), career maturity (Savickas \& Jarjoura, 1991), locus of control (Cellini \& Kantorowski, 1984), self-efficacy and career self-efficacy (Hirschi, 2014; Li et al., 2019; Restubog et al., 2010), school-to-work transition (Arnold, 1989), social support (Hirschi et al., 2011), subjective wellbeing (Arnold, 1989; Lounsbury et al., 1999), and hope (Hirschi, 2014).

\section{Subjective Wellbeing}

University students who lack career decidedness and do not change their lives may pay a heavy toll (Reyna \& Farley, 2006). These costs are not limited to low academic success (Prevatt et al., 2011); students' subjective wellbeing may also be negatively affected (Arnold, 1989; Lounsbury et al., 1999; Lounsbury et al., 2005; Uthayakumar et al., 2010). Subjective wellbeing is measured by an individual's feelings and thoughts about their own lives (Diener, 1984; 2000); it contains both positive and negative emotions and life satisfaction (Diener, 1984). Individuals' cognitive evaluation based on their criteria and emotions about their lives and emotions shows their subjective wellbeing level. Having a high level of subjective 
wellbeing indicates an ideal level of human functioning (Keyes, 2005). Subjective wellbeing has been researched in many studies in terms of career success, such as career construction (Hartung \& Taber, 2008), career adaptability (Ramos \& Lopez, 2018; Konstam et al., 2015), career satisfaction (Joo \& Lee, 2017), and career commitment (Singhal \& Rastogi, 2018).

Importantly, while Eryilmaz and Ercan (2011) say that the 19-25 age group, which corresponds to the university years, has a lower subjective wellbeing level than the younger and older age groups, Braun (1977) posits that as people grow older, the intensity of emotions decreases, and the life satisfaction increases. This view supports Super's (1980) view that university students' emotional aspects predominate when making decisions. It follows that questioning career decisions and reconstructing career planning can negatively affect individuals' happiness and life satisfaction (Hirschi, 2014). The importance of the relationship between career decidedness and subjective wellbeing is seen in university students, where emotions is an important for career decision making.

\section{Hope as a Mediator}

An important factor studied with the concept of career decidedness is hope. Hope, one of our ten most important positive emotions, has many different definitions (Henley, 2017; Schrank et al., 2008). Synder et al. (1991) defined hope as "a cognitive set that is based on a reciprocally derived sense of successful (a) agency (goal-directed determination) and (b) pathways (planning of ways to meet goals)" (p. 571). Hope is a positive emotion caused by the cognitive process that involves a relevant thought playing an important role in overcoming a problem in difficult situations and believing that it will end with the desired result in the future (Bloeser \& Stahl, 2017; Cohen-Chen et al., 2017; Frijda, 1986). Hope, which is an important feeling in most individuals' lives, can significantly influence career pathways (Cohen-Chen et al., 2017; Owen et al., 2012; Şimşek, 2013). University students who have clear hopes for their future profession have higher professional commitment than those who do not (Hirschi, 2014). For example, relevant studies and statistics in Turkey show that as the employment rates of a department's graduates increase, their dropout rates decrease (e.g., Bülbül, 2012; Şimşsek, 2013). More hopeful people are more creative; they see more opportunities and show more decidedness to achieve their goals, which leads to higher levels of happiness, more successful careers, and a positive subjective wellbeing (Bailey et al., 2007; Pleeging et al., 2019; Snyder, 2000). People with high hopes are expected to have more positive emotions, high life satisfaction, and low negative emotions, all leading to a higher level of subjective wellbeing (Bailey \& Snyder, 2007; Muyan-Y1lık \& Demir, 2019; Peterson \& Seligman, 2004; Synder, 2002; Yalçın \& Malkoç, 2015).

\section{Aim of the Study}

The career decidedness of university students is one of the most important points in timing, academic, social, and personal factors. Previous studies have found a positive correlation between career decidedness and hope, career decidedness and subjective wellbeing , and hope and subjective wellbeing. However, to our knowledge, how hope influences the relationship between career decidedness and subjective wellbeing has not yet been studied. As career decidedness increases, we anticipate that hope levels will increase, thereby increasing university students' level of subjective wellbeing. Thus, two hypotheses are tested in this study.

(1) There is a positive correlation between career decidedness, hope, and subjective wellbeing. 
(2) Hope plays a mediating role in the relationship between career decidedness and subjective wellbeing (Figure 1).

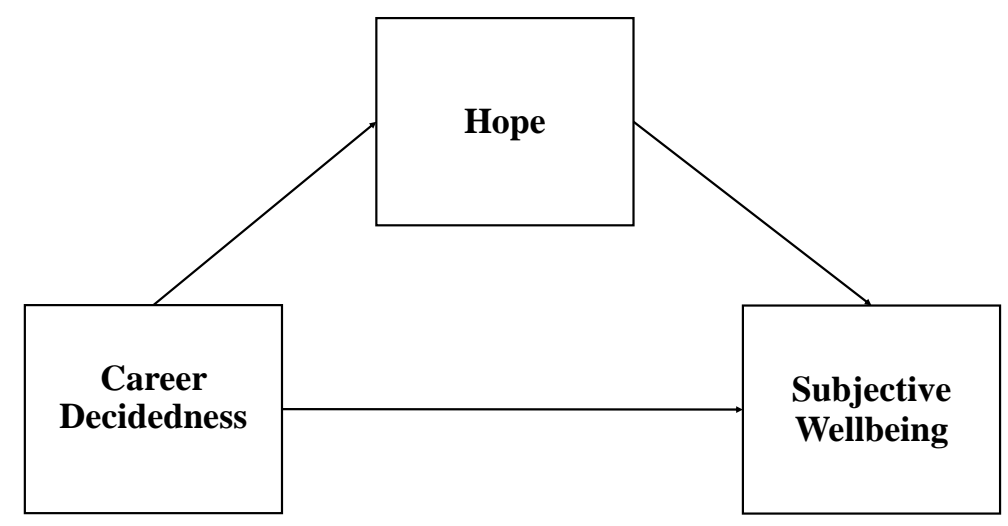

Figure 1. Hypothesized Model

\section{Method}

\section{Sample}

The data was collected from university students enrolled in public universities in İzmir, Turkey (Table 1). A total of 376 undergraduate students (269 females and 107 males $[M=$ $22.17, S D=5.10]$ ) have participated in this study. Participant students were enrolled as fulltime students and divided into 86 freshmen (23\%), 128 sophomores (34\%), 98 juniors (25\%) and 64 seniors (17\%) during the 2020-2021 academic year. Only $4 \%$ of the participants stated that they had received career counseling; the rest did not receive any career counseling in any part of their lives.

Table 1. Participant Information

\begin{tabular}{llll} 
& & N & $\%$ \\
\hline \multirow{2}{*}{ Gender } & Female & 269 & 72 \\
& Male & 107 & 28 \\
& Freshmen & 86 & 23 \\
& Sophomores & 128 & 34 \\
& Junior & 98 & 25 \\
Received Career Counseling & Senior & 64 & 17 \\
& Yes & 15 & 4 \\
\hline
\end{tabular}




\section{Procedure}

The ethics committee from the researcher's university approved all steps of this study. Participants were informed about volunteerism, the data will only be used for researchers' educational purposes, and the contact information will only be used to meet the ethical requirements. All participants gave informed consent, which was also included in the survey forms. Questionnaire links were sent to social media accounts of university students in İzmir three times at regular intervals. A G power program used or for selected analysis path and when the number of participants reached a certain number, data collection was stopped, and data analysis was started (Faul et al., 2009).

\section{Instruments}

\section{Dispositional Hope Scale}

Dispositional Hope Scale (DHS) was developed by Snyder et al. (1991) and adapted to Turkish by Tarhan and Bacanlı (2015). DHS is an eight-point Likert scale and includes 12 items within two dimensions: agency and pathway. Each dimension consists of four items, and the remaining four items are filling items. Higher scores on the scale mean a higher level of dispositional hope. Snyder et al. (1985) calculated that the reliability coefficients ranged between .74 - .84, whereas Tarhan and Bacanl1 (2015) calculated it as .84. We calculated reliability coefficient as .86 in this study.

\section{Career Decidedness Scale}

Career Decidedness Scale (CDS), which has been developed by Lounsbury et al. (1999) and adapted to Turkish by Akçakanat and Uzunbacak (2019), is a five-point Likert scale consisted of six items in a single factor. Higher scores mean a higher level of career decidedness. Lounsbury et al. (1999) calculated the overall scale's reliability coefficient as .95, and Akçakanat and Uzunbacak (2019) calculated it as .80. We calculated Cronbach's alpha coefficient as .81 in this study.

\section{Positive and Negative Affect Schedule}

Positive and Negative Affect Schedule (PANAS), developed by Watson et al. (1988), was adapted to Turkish by Gençoz (2000). PANAS is a five-point Likert scale and includes ten positive and ten negative emotions. Positive and negative emotion scores are calculated separately. Higher scores on each scale mean a higher level of positive or negative emotions. Watson et al. (1998) calculated the Cronbach alpha coefficient of positive emotions as .88 and negative ones as .85; Gençoz (2000) calculated it as .83 for positive emotions and as .86 for negative ones. We calculated Cronbach's alpha reliability coefficient for positive emotions as .88 and negative ones as .84 in this study.

\section{Satisfaction with Life Scale}

Satisfaction with Life Scale (SWLS) was developed by Diener et al. (1985) and adapted to Turkish by Koker (1991). SWLS is a single factor, seven-point Likert scale, which includes five items. Higher scores on the scale mean a higher level of life satisfaction. Cronbach's alpha coefficient for the original study was .85; it was .85 for the Turkish version, and it was found to be .81 in this study. 


\section{Data analysis}

Cronbach Alpha coefficient, Pearson Correlation coefficient, and PROCESS Model 4 were used to evaluate the measurements. Cronbach alpha coefficient is considered to be a measure of scale reliability. Pearson Correlation coefficient is the test statistic that measures the statistical relationship, or association, between two continuous variables; it was used to measure the bivariate correlation between total scores of DHS, CDS, PANAS, SWLS, and subjective wellbeing. PROCESS bootstrapped mediation analysis (Hayes, 2013) was used to test the hypothesized model, using which was the mediating role of hope between career and subjective wellbeing was analyzed. Hayes (2013) created this tool, and it has been used in social sciences commonly since then. PROCESS is a specific regression tool to analyzing method in a model. PROCESS creates intervals for mediating and/or moderating roles of variables between dependent and independent variables. Interval of indirect effects are measured with direct effects and internals which do not include zero are statistically significant (Hayes, 2013). There are many models in PROCESS tool and Model 4, which was used in this study, creates opportunity to measure one or more mediation between variables in addition to bivariate correlations.

Subjective wellbeing cannot be measured directly like career decidedness and hope. Diener (1984) described subjective wellbeing with life satisfaction and emotions (Diener, 1984). Based on Diener's description, the tools widely used to measure subjective wellbeing are the SWLS (Diener et al., 1985) involving life satisfaction and PANAS (Watson et al., 1988) involving emotions. Researchers use these scales in various ways to calculate subjective wellbeing; one of them is subjective wellbeing as a composite (Andrews \& Crandall, 1976; Busseri \& Sadava, 2011), which has been used by several researchers (e.g., Doğan \& Eryılmaz, 2013; Miranda \& Cruz, 2020; Sağkal \& Türnüklü, 2017). In this model, the integration of life satisfaction $(+)$, positive emotions (+), and negative emotions (-) reflect subjective wellbeing; the correlation between these factors is not primarily important (Busseri \& Sadava, 2011).

\section{Results}

Regarding Cronbach's alpha reliability coefficients, all scales had a good level of reliability as mentioned in measurements section $(\mathrm{DHS}=.86, \mathrm{CDS}=.81$, PANAS-P $=.88$, PANAS-N $=.84$, SWLS $=.81$ ). Pearson correlation analyses showed positive correlations between DHS, CDS, PANAS-P, SWLS, and subjective wellbeing. As expected, negative correlations were observed between PANAS-N and DHS, CDS, PANAS-P, SWLS, and subjective wellbeing (Hypothesize 1). The model was tested by PROCESS (Hayes 2013), and the results supported the mediating role of hope between career decidedness and subjective wellbeing (Hypothesize 2; Figure 2).

\section{Correlation Analysis}

Pearson correlation analysis was used to measure bivariate correlations between variables (Hypothesize 1). The results showed that all variables have expected association with each other (Table 2). Career decidedness and subjective wellbeing were significantly and positively correlated. The correlation between career decidedness and hope was also statistically significant and positive. Regarding the correlation of hope with subjective wellbeing, there was a statistically significant relationship. As expected, career decidedness and hope were positively correlated with positive emotions and life satisfaction and negatively with negative emotions as sub-dimensions of subjective wellbeing.

Table 2. Bivariate Correlations $(* * \mathrm{p}<0.001, * \mathrm{p}<0.01)$ 
(1)

(2)

(3)

(4)

(5)

(6)

Career Decidedness Scale (1)

Dispositional Hope Scale (2)

Satisfaction with Life Scale (3)

Positive and Negative Affect Schedule-Positive (4)

Positive and Negative Affect Schedule-Negative (5)

Subjective Wellbeing (6)

Mean

$.40^{* *} \quad .48^{* *} \quad .57^{* *} \quad .77^{* *}$

20.95

47.83

16.72

23.57

28.27

21.41

Standard Deviation

$\begin{array}{llllll}4.64 & 7.67 & 3.69 & 7.36 & 8.04 & 13.38\end{array}$

\section{Mediation analysis}

Hayes's (2013) macro PROCESS Model 4 in SPPS was used to analyses data. With 5000 bootstrap samples and $95 \%$ bias-corrected confidence interval the mediating role in the hypothesized model were observed (Hypothesize 2; Figure 2). The path (direct effect) from career decidedness to hope was positive and statistically significant $(b=.76$, s.e. $=.08, p<$ .001 ). The path (direct effect) from career decidedness to subjective wellbeing was positive and statistically significant $(\mathrm{b}=.63$, s.e. $=.11, p<.001)$, indicating that university students having higher career decidedness scores were more likely to express subjective wellbeing than those with lower scores. The direct effect of hope on subjective wellbeing was positive and significant $(\mathrm{b}=.66$, s.e. $=.09, p<.001)$, indicating that people with higher hope scores were more likely to express a better subjective wellbeing than those having low scores.

PROCESS results using non-parametric bootstrapping with 5000 samples showed that the indirect effect of hope as a mediator between career decidedness and subjective wellbeing was .50; the total indirect effects of career decidedness and hope on subjective wellbeing was 1.1281. To confirm indirect effect' statistical significance, the lower limit confidence interval (LLCI) and upper limit confidence interval (ULCI) should not be zero (Preacher \& Hayes, 2004). In this study, LLCI and ULCI of hope were .33 and .69 , respectively ( $p<0.05)$. LLCI and ULCI of the total indirect effects of hope and career decidedness on subjective wellbeing were .86 and 1.40 , respectively $(p<0.05)$. Since both LLCI and ULCI values $\neq 0$, the hypothesized indirect effect was proved to be significantly significant (Figure 2). 


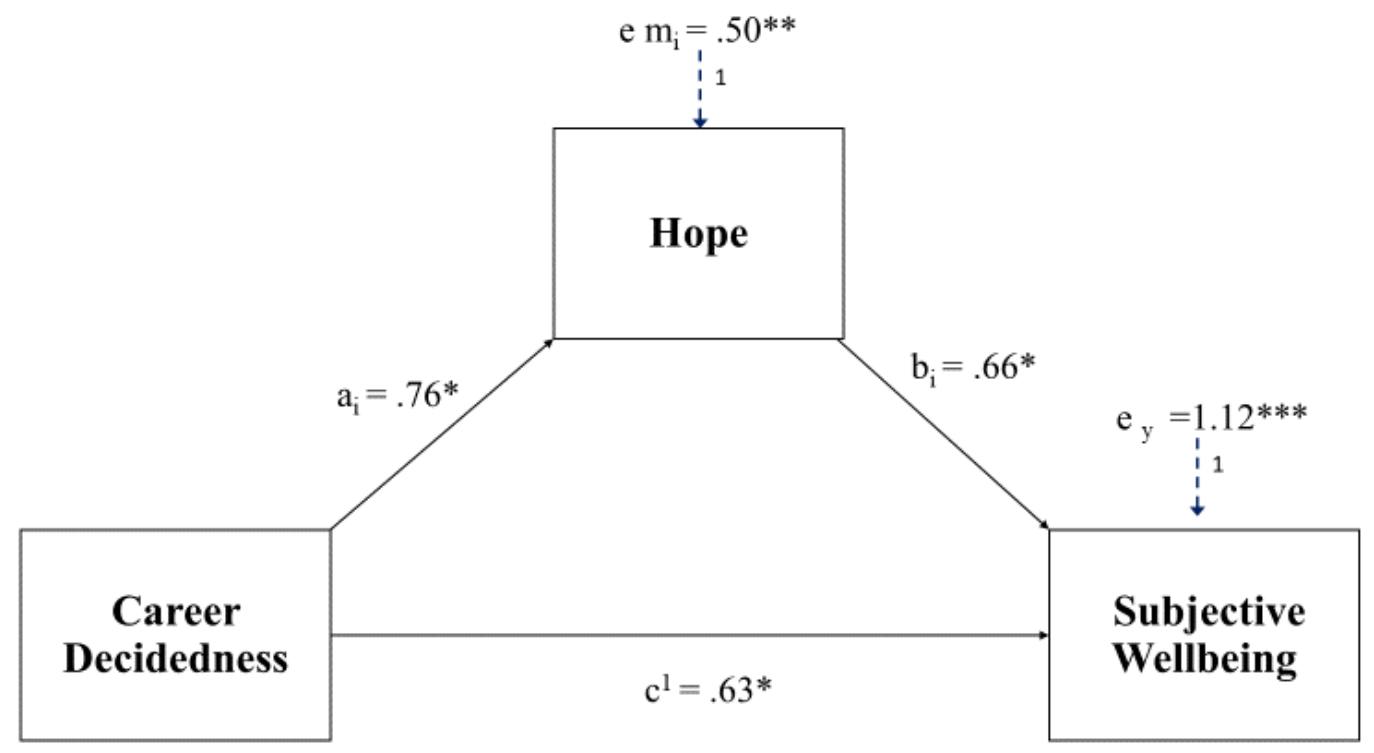

Figure 2. ${ }^{*} \mathrm{p}<0.001,{ }^{*} \mathrm{e} \mathrm{m}_{\mathrm{i}}:$ the indirect effect, $* * * \mathrm{e}_{\mathrm{y}}$ : the total indirect effect

\section{Discussion}

The purpose of this study was to examine the mediating role of hope in the relationship between career decidedness and subjective well-being. The results showed that career decidedness, hope, and subjective wellbeing are positively associated with each other; this supported our model that hope significantly mediated the relationship between career decidedness and subjective wellbeing. First, our results were consistent with the available literature that career decidedness had a significant and positive correlation with subjective wellbeing (Arnold, 1989; Lounsbury et al., 1999; Lounsbury et al., 2005; Uthayakumar et al., 2010). Having a certain career decision and having fewer doubts increases hope for achieving that career, which may increase life satisfaction and positive emotions and decrease negative emotions. These results showed the importance of university students' views on their career decisions. Even though life dynamics may be unstable during university life (Yan \& Yue-jia, 2005), it is still important for university students to make career decisions (Evans et al., 2009; Super, 1980). Changing career paths can cost a significant amount of time and money and can cause stress and significant changes in a person's life after entering university (Şimşek, 2013). Therefore, knowing and understanding the outcomes of choosing a career before entering university can help students improve career decidedness and, importantly, decrease withdrawal costs during university, ultimately increasing subjective wellbeing.

Second, Owen et al. (2010) and Şimşek (2013) mentioned high employment opportunities as the main reason for choosing a career in Turkey. In addition, having the hope to be employed is important (Super, 2000). Our correlational results supported that hope is a significant factor for university students to maintain their career decidedness. Similarly, our direct effect results showed that career decidedness positively affects university students' hope levels. Hirschi (2014) states the importance of hope for individuals' career pathways. In addition to his findings, our results showed that career decidedness also increased the level of hope. University students with career decidedness had a more optimistic view of the future.

Third, regarding the analysis results, hope had a direct effect on subjective wellbeing. These 
results were similar to the literature (Bailey \& Synder, 2007; Muyan-Y1lik \& Demir, 2019; Peterson \& Seligman, 2004; Synder, 2002; Yalçın \& Malkoç, 2015). Having high hope increased positive emotions and life satisfaction and decreased negative emotions. Therefore, it positively and directly influenced subjective wellbeing.

\section{Does hope mediate the link?}

This study found that career decidedness positively influenced subjective wellbeing through hope. When university students' career decidedness and hope increase, their life satisfaction and positive emotions increase, and negative emotions decrease, improving overall subjective wellbeing. This study has once again demonstrated that hope is a positive factor in career development (Cohen-Chen et al., 2017). This situation may enhance the perseverance of university students who will face many difficulties in their career path. Importantly, hope positively affects the emotions and life satisfaction that constitute wellbeing. Life satisfaction is lower in young people, and their emotional lability is fast and high (Eryilmaz \& Ercan, 2011); hope can help keep a positive attitude in this age group. In addition to academic, social, and personal variables in career development, considering hope as a valuable factor can positively affect the counseling process.

Consequently, establishing a goal through career decidedness, improves hope and the belief that the future goals can be achieved increases subjective wellbeing. Understanding students' career pathways and reinforcing their positive feelings towards their future can create a helpful university environment. Creating programs to increase both career decidedness and improve hope can help to improve university students' subjective wellbeing. With a high level of subjective wellbeing, university students will show better mental health, interpersonal relationships, and social and cognitive functioning (Lyubomirsky et al., 2005; Pressman \& Cohen, 2005). Student development in university presents many opportunities for university students to advance their careers. The important findings of this study are the significance of hope and career decidedness on career opportunities, approaching them positively, reinforcing decidedness, and most importantly, providing the opportunity to realize student goals. This study is also important in establishing the importance of career decidedness and the effect of hope on positive and negative emotions of university students living in an emotionally important period.

\section{Conclusion}

This study revealed the positive effects of both career decidedness and hope on university students' subjective wellbeing. First, to achieve career decidedness, the individual needs to know their career path, and their strengths, interests, and abilities (Holland, 1973). Supporting this is the fundamental goal of career counseling. As a result of the effective execution of career counseling in high schools and universities, students will make better decisions and maintain their decisions by knowing both their professions and themselves, which will positively impact their subjective wellbeing. To increase the competencies of career counselors about supporting the hope of university students regarding their career issues is important (Eraslan-Çapan \& Korkut-Owen, 2017). Second, supporting university students' hope about their career-related goals, and increasing their career decidedness will likely improve subjective wellbeing. Thus, counselors might use the motivation of hope for career issues and needs for students.

Based on descriptive results, only $4 \%$ percent of participants received career counseling support. Students qualify to enter university in Turkey with a combination of their university 
entrance exam scores and high school graduation grades. Moving to other departments or preparing for the next exam to change departments and be admitted to university is challenging. Therefore, one of the most important periods for career counseling seems to be high school, when wasted costs may be minimized. Simultaneously, students need career counseling about how to progress in their careers after entering university or in case of a career change; this period is as important as high school. Although Turkish Higher Education requires counseling centers at universities, still most of universities does not offer career counseling. Although there are have been positive developments, such as the Turkish Counseling Association beginning to publish a career counseling journal and some universities adopting career counseling masters, and doctorate programs (e.g., Boğaziçi University-Istanbul), very few participants of this study stated that they received professional assistance before and during their university life for their careers (Şahin et al., 2018; Yeşilyaprak, 2019). Increasing the quantity of career counseling services should be an important goal for the career counseling services of university students in Turkey.".

\section{Limitations and Suggestions}

This study has several limitations. In this descriptive and correlational study, data were collected through cross-sectional design from university students by social media pages in Izmir, Turkey, in 2020. Therefore, the participants are limited to the students enrolled on social media pages in a city (Izmir) and in a specific time frame (2020); therefore, the chosen sample and timing limits generalizability (Bowen \& Wiersema, 1999). This study might also have validity threats because results are based on participants' statements, without confirmation of whether they are true or not (Fraenkel et al., 2012).

As seen in literature, positive psychology has been expanded rapidly in all counseling areas (Wong \& Roy, 2018). The main reason for this explosion is evidence that positive psychology contributes to clients. It is found that supporting the strengths of clients helps them to realize their strengths, cope with their problems, create solutions, and to be optimistic for their future, especially in their careers. Hope is at the core of these dimensions to enhance subjective wellbeing, which is life satisfaction and positive emotion. In addition, to be certain in career pathways, increasing hope will help clients. Hope already influences $\% 15$ of the counseling in terms of clients' success in sessions (Asay \& Lambert, 1999), and counselors and counselor educators need to pay more attention to hope. Also, for future studies, it is suggested to employ longitudinal design or a larger sample size to examine university students' perception of their careers and their relationships with their hope and wellbeing dimensions.

\section{References}

Akçakanat, T., \& Uzunbacak, H. H. (2019). Career stability scale: Adaptation to Turkish, validity and reliability study. Journal of Economic Administrative and Political Research, 4(9), 159-170.

Andersen, P., \& Vandehey, M. (2011). Career counseling and development in a global economy. Cengage Learning.

Andrews, F. M., \& Crandall, R. (1976). The validity of measures of self-reported. Social Indicators Research, 3, 1-19. https://doi.org/10.1007/BF00286161

Arnold, J. (1989), Career decidedness and psychological well-being: A two-cohort longitudinal study of undergraduate students and recent graduates. Journal of Occupational Psychology, 62, 163-176. https://10.1111/j.2044-8325.1989.tb00487.x 
Asay, T. P., \& Lambert, M. J. (1999). The empirical case for the common factors in therapy: Quantitative findings. In M. A. Hubble, B. L. Duncan, \& S. D. Miller (Eds.), The heart and soul of change: What works in therapy (pp. 23-55). American Psychological Association. https://doi.org/10.1037/11132-001

Bailey, T. C., \& Snyder, C. R. (2007). Satisfaction with life and hope: A look at age and marital status. The Psychological Record, 57(2), 233-240. https://doi.org/10.1007/BF03395574

Bjork, J. M., Knutson, B., Fong, G. W., Caggiano, D. M., Bennett, S. M., \& Hommer, D. W. (2004). Incentive-elicited brain activation in adolescents: similarities and differences from young adults. Journal of Neuroscience, 24(8), https://doi.org/17931802.10.1523/JNEUROSCI.4862-03.2004

Blöser, C., \& Stahl, T. (2017). Fundamental hope and practical identity. Philosophical Papers, 46(3), 345-371. https://doi.org/10.1080/05568641.2017.1400918

Bowen, H. P., \& Wiersema, M. F. (1999). Matching method to paradigm in strategy research: limitations of cross-sectional analysis and some methodological alternatives. Strategic Management Journal, 20(7), 625-636. https://doi.org/10.1002/(SICI)10970266(199907)20:7<625::AID-SMJ45>3.0.CO;2-V

Braun, P. M. W. (1977). Psychological well-being and location in the social structure (Doctoral dissertation, No: 778463). USC Digital Library. University of Southern California.

Busseri, M. A., \& Sadava, S. W. (2011). A review of the tripartite structure of subjective wellbeing: Implications for conceptualization, operationalization, analysis, and synthesis. Personality and Social Psychology Review, 15(3), 290-314. https://doi.org/10.1177/1088868310391271

Bülbül, T. (2012). School dropout in higher education: Causes and solutions. Education and Science, 37(166), 219-235.

Campagna, C. G., \& Curtis, G. J. (2007). So worried I don't know what to be: Anxiety is associated with increased career indecision and reduced career certainty. Australian Journal of Guidance and Counselling, 17(1), 91-96. https://doi.org/ 10.1375/ajgc.17.1.91

Cellini, J. V., \& Kantorowski, L. A. (1984). Locus of control and career decidedness: Some methodological notes. Psychological Reports, 55(2), 613-614. https://doi.org/10.2466/pr0.1984.55.2.613

Cohen-Chen, S., Crisp, R. J., \& Halperin, E. (2017). A new appraisal-based framework underlying hope in conflict resolution. Emotion Review, 9(3), 208-214. https://doi.org/10.1177/1754073916670023

Diener, E. (1984). Subjective well-being. Psychological Bulletin, 95(3), 542-575. https://doi.org/10.1037/0033-2909.95.3.542

Diener, E. (2000). Subjective well-being: The science of happiness and a proposal for a national index. American Psychologist, 55(1), 34-43. https://doi.org/10.1037/0003066X.55.1.34

Diener, E., Emmons, R. A., Larsen, R. J., \& Griffin, S. (1985). The Satisfaction With Life Scale. Journal of Personality Assessment, 49(1), 71-75. https://doi.org/10.1207/s15327752jpa4901_13

Doğan, T. \& Eryılmaz, A. (2013). Examining the relationships between two-dimensional selfesteem and subjective well-being. Pamukkale University Journal of Education, 33, 107117.

Eraslan-Çapan, B., \& Korkut-Owen, F. (2017). Preferences among high school students for university study areas and career counselling. Electronic Social Science Journal, 16(61), 551-568. 
Eryılmaz, A., \& Ercan, L. (2011). Analysis of subjective well-being in terms of gender, age groups and personality traits. Turkish Psychological Counseling and Guidance Journal, 4(36), 139-151.

Evans, N. J., Forney, D. S., Guido, F. M., Patton, L. D., \& Renn, K. A. (2009). Student development in university: Theory, research, and practice. John Wiley \& Sons.

Faul, F., Erdfelder, E., Buchner, A., \& Lang, A. G. (2009). Statistical power analyses using G* Power 3.1: Tests for correlation and regression analyses. Behavior research methods, 41(4), 1149-1160. https://doi.org/10.3758/BRM.41.4.1149

Fitzpatrick, C., \& Costantini, K. (2012). Counseling 21st century students for optimal university and career readiness: A 9 th-12th grade curriculum. Routledge.

Fraenkel, J. R., Wallen, N. E., \& Hyun, H. H. (2012). How to design and evaluate research in education (Eight Edition). McGraw-Hill.

Frijda, N. H. (1986). The emotions. Cambridge University Press.

Gati, I., \& Asher, I. (2001). The PIC model for career decision making: Prescreening, in-depth exploration, and choice. In T. L. Leong, \& A. Barak (Eds.), Contemporary models in vocational psychology: A volume in honor of Samuel H. Osipow (pp. 6-54). Mahwah, NJ: Erlbaum.

Gençöz, T. (2000). Positive and negative emotion scale: Validity and reliability study. Turkish Journal of Psychology], 15(46), 19-26.

Hartung, P. J., \& Taber, B. J. (2008). Career construction and subjective well-being. Journal of Career Assessment, 16(1), 75-85. https://doi.org/10.1177/1069072707305772

Hayes, A. F. (2013). Methodology in the social sciences.Introduction to mediation, moderation, and conditional process analysis: A regression-based approach. Guilford Press.

Henley, K. (2017). What are the top ten positive emotions? Huffington Post. https://www. huffingtonpost.com/kari-henley/what-are-the-top-10-posit_b_203797.html (Accessed on June 11th, 2020).

Herrnstein, R. J., \& Prelec, D. (1991). Melioration: A theory of distributed choice. Journal of Economic Perspectives, 5(3), 137-156. https://doi.org/10.1257/jep.5.3.137

Hinkelman, J. M., \& Luzzo, D. A. (2007). Mental health and career development of university students. Journal of Counseling \& Development, 85(2), 143-147. https://doi.org/10.1002/j.1556-6678.2007.tb00456.x

Hirschi, A. (2014). Hope as a resource for self-directed career management: Investigating mediating effects on proactive career behaviors and life and job satisfaction. Journal of Happiness Studies, 15(6), 1495-1512. https://doi.org/10.1007/s10902-013-9488-x

Hirschi, A., Niles, S. G., \& Akos, P. (2011). Engagement in adolescent career preparation: Social support, personality and the development of choice decidedness and congruence. Journal of Adolescence, 34(1), 173-182. https://doi.org/10.1016/j.adolescence.2009.12.009

Holland, J. L. (1973). Making vocational choices: A theory of careers. J. Holland.

Joo, B. K., \& Lee, I. (2017, August). Workplace happiness: Work engagement, career satisfaction, and subjective well-being. In Evidence-based HRM: A Global Forum for Empirical Scholarship. Emerald Publishing Limited.

Judge, T. A., \& Bretz, R. D. (1992). Effects of work values on job choice decisions. Journal of Applied Psychology, 77(3), 261-271. https://doi.org/10.1037/0021-9010.77.3.261

Keyes, C. L. M. (2005). Mental Illness and/or Mental Health? Investigating Axioms of the Complete State Model of Health. Journal of Consulting and Clinical Psychology, 73(3), 539-548. https://doi.org/10.1037/0022-006X.73.3.539

Konstam, V., Celen-Demirtas, S., Tomek, S., \& Sweeney, K. (2015). Career adaptability and subjective well-being in unemployed emerging adults: A promising and cautionary 
tale. Journal of Career Development, 42(6), 463-477. https://doi.org/10.1177/0894845319847006

Köker, S. (1991). Comparison of Normal and Problematic Adolescents' Life Satisfaction Level. (Master's Thesis, Thesis No. 16802) Council of Higher Education Thesis Center, Ankara University.

Li, H., Ngo, H. Y., \& Cheung, F. (2019). Linking protean career orientation and career decidedness: The mediating role of career decision self-efficacy. Journal of Vocational Behavior, 115, 103322, 1-11, https://doi.org/10.1016/j.jvb.2019.103322

Lounsbury, J. W., Hutchens, T., \& Loveland, J. M. (2005). An investigation of big five personality traits and career decidedness among early and middle adolescents. Journal of Career Assessment, 13(1), 25-39.

Lounsbury, J. W., Tatum, H. E., Chambers, W., Owens, K. S., \& Gibson, L. W. (1999). An investigation of career decidedness in relation to "Big Five" personality constructs and life satisfaction. University Student Journal, 33(4), 646-652.

Lyubomirsky, S., Sheldon, K. M., \& Schkade, D. (2005). Pursuing happiness: The architecture of sustainable change. Review of General Psychology, 9(2), 111131. https://doi.org/10.1037/1089-2680.9.2.111

Miranda, J.O., Cruz, R.N.C. (2020). Resilience mediates the relationship between optimism and well-being among Filipino university students. Current Psychology. https://doi.org/10.1007/s12144-020-00806-0

Muyan-Y1lık, M., \& Demir, A. (2019). A pathway towards subjective well-being for Turkish university students: the roles of dispositional hope, cognitive flexibility, and coping strategies. Journal of Happiness Studies, 1-19. https://doi.org/10.1007/s10902-01900162-2

Oktay, R. S. (2019). In Turkey, the increase in the number of university dropouts. Deutsche Welle. $\quad$ https://www.dw.com/tr/t\%C3\%BCrkiyede-\%C3\%BCniversiteyiyar\%C4\%B1da-b\%C4\%B1rakanlar\%C4\%B1n-say\%C4\%B1s\%C4\%B1art\%C4\%B1\%C5\%9Fta/a-47696368

Osipow, S. H. (1999). Assessing career indecision. Journal of Vocational Behavior, 55(1), $147-$ 154. https://doi.org/10.1006/jvbe.1999.1704

Owen, F. K., Kepir, D., Özdemir, S., Ulaş, Ö., \& Y1lmaz, O. (2012). University students' reasons to choose a department. Mersin University Education Faculty Journal, 8(3), 135-151.

Peterson, C., \& Seligman, M. E. P. (2004). Character strengths and virtues: A handbook and classification. APA Press and Oxford University Press.

Pleeging, E., Burger, M., \& van Exel, J. (2019). The relations between hope and subjective well-being: A literature overview and empirical analysis. Applied Research in Quality of Life, 1-23. https://doi.org/10.1007/s11482-019-09802-4

Preacher, K. J., \& Hayes, A. F. (2004). SPSS and SAS procedures for estimating indirect effects in simple mediation models. Behavior Research Methods, Instruments, \& Computers, 36(4), 717-731. https://doi.org/10.3758/BF03206553

Pressman, S. D., \& Cohen, S. (2005). Does positive affect influence health? Psychological Bulletin, 131(6), 925-971. https://doi.org/10.1037/0033-2909.131.6.925

Prevatt, F., Li, H., Welles, T., Festa-Dreher, D., Yelland, S., \& Lee, J. (2011). The academic success inventory for university students: scale development and practical 1mplications for use with students. Journal of University Admission, 211, 26-31.

Ramos, K., \& Lopez, F. G. (2018). Attachment security and career adaptability as predictors of subjective well-being among career transitioners. Journal of Vocational Behavior, 104, 72-85. https://doi.org/10.1016/j.jvb.2017.10.004 
Rand, K. L., \& Cheavens, J. S. (2009). Hope theory. In S. J. Lopez \& C. R. Snyder (Eds.), Oxford library of psychology. Oxford handbook of positive psychology (p. 323333). Oxford University Press.

Restubog, S. L. D., Florentino, A. R., \& Garcia, P. R. J. M. (2010). The mediating roles of career self-efficacy and career decidedness in the relationship between contextual support and persistence. Journal of Vocational Behavior, 77(2), 186-195. https://doi.org/10.1016/j.jvb.2010.06.005.

Reyna, V. F., \& Farley, F. (2006). Risk and rationality in adolescent decision making: Implications for theory, practice, and public policy. Psychological Science in the Public Interest, 7(1), 1-44. https://doi.org/10.1111/j.1529-1006.2006.00026.x

Sağkal, A. S., \& Türnüklü, A. (2017). Effects of peace education program on subjective wellbeing and hope levels of high school students. Turkish Psychological Counseling and Guidance Journal], 7(47), 69-85

Savickas, M. L. (2005). The Theory and Practice of Career Construction. In S. D. Brown \& R. W. Lent (Eds.), Career development and counseling: Putting theory and research to work (p. 42-70). John Wiley \& Sons, Inc.

Savickas, M. L., \& Jarjoura, D. (1991). The Career Decision Scale as a type indicator. Journal of Counseling Psychology, 38(1), 85-90. https://doi.org/10.1037/0022-0167.38.1.85

Schrank, B., Stanghellini, G., \& Slade, M. (2008). Hope in psychiatry: a review of the literature. Acta Psychiatrica Scandinavica, 118(6), 421-433.

Serlachius, A., Hamer, M., \& Wardle, J. (2007). Stress and weight change in university students in the United Kingdom. Physiology \& Behavior, 92(4), 548-553. https://doi.org/10.1016/j.physbeh.2007.04.032

Singhal, H., \& Rastogi, R. (2018). Psychological capital and career commitment: the mediating effect of subjective well-being. Management Decision, 56(2), 458-473. https://doi.org/10.1108/MD-06-2017-0579

Snyder, C. R. (2000). The past and possible futures of hope. Journal of Social and Clinical Psychology, 19(1), 11-28. https://doi.org/10.1521/jscp.2000.19.1.11

Snyder, C. R. (2002). Hope theory: Rainbows in the mind. Psychological Inquiry, 13(4), 249 275. https://doi.org/10.1207/S15327965PLI1304_01.

Snyder, C. R., Harris, C., Anderson, J. R., Holleran, S. A., Irving, L. M., Sigmon, S. T., Yoshinobu, L., Gibb, J., Langelle, C., \& Harney, P. (1991). The will and the ways: development and validation of an individual-differences measure of hope. Journal of Personality and Social Psychology,60(4), 570-585. https://doi.org/10.1037//00223514.60.4.570

Super, D. E. (1980). A life-span, life-space approach to career development. Journal of Vocational Behavior, 16(3), 282-298. https://doi.org/10.1016/0001-8791(80)90056-1

Şahin, C., Büyükgöze Kavas, A., \& Öztemci, K. (2018). From Editors. Journal of Career Psychological Counseling, (1)1, ii.

Şimşek, H. (2013). University students' disposition trends and reasons. Journal of Theoretical Educational Science, 6(2), 242-271.

Tarhan, S., \& Bacanl1, H. (2015). Adaptation of the dispositional hope scale to Turkish: Validity and reliability study. The Journal of Happiness \& Well-Being, 3(1), 1-14.

Uthayakumar, R., Schimmack, U., Hartung, P. J., \& Rogers, J. R. (2010). Career decidedness as a predictor of subjective well-being. Journal of Vocational Behavior, 77(2), 196-204. https://doi.org/10.1016/j.jvb.2010.07.002

Watson, D., Clark, L. A., \& Tellegen, A. (1988). Development and validation of brief measures of positive and negative affect: The PANAS scales. Journal of Personality and Social Psychology, 54(6), 1063-1070. https://doi.org/10.1037/0022-3514.54.6.1063 
Wong, P. T. P., \& Roy, S. (2018). Critique of positive psychology and positive interventions. In N. J. L. Brown, T. Lomas, \& F. J. Eiroa-Orosa (Eds.), The Routledge international handbook of critical positive psychology (pp. 142-160). Routledge/Taylor \& Francis Group.

Yalçın, İ., \& Malkoç, A. (2015). The relationship between meaning in life and subjective wellbeing: Forgiveness and hope as mediators. Journal of Happiness Studies, 16(4), 915929. https://doi.org/10.1007/s10902-014-9540-5

Yan, W., \& Yue-jia, L. (2005). Standardization and assessment of university students' facial expression of emotion. Chinese Journal of Clinical Psychology, 13(4), 396-398.

Yeşilyaprak, B. (2019). Guidance Services in Education. Nobel. 